\title{
Lamivudine Treatment Can Restore T Cell Responsiveness in Chronic Hepatitis B
}

\author{
Carolina Boni, ${ }^{*}$ Antonio Bertoletti, ${ }^{*}$ Amalia Penna, ${ }^{*}$ Albertina Cavalli, ${ }^{*}$ Massimo Pilli, ${ }^{*}$ Simona Urbani, ${ }^{*}$ Paola Scognamiglio, \\ Richard Boehme, ${ }^{\ddagger}$ Ruggero Panebianco, ${ }^{\S}$ Franco Fiaccadori, ${ }^{\star}$ and Carlo Ferrari* \\ * Laboratorio di Immunopatologia Virale, Divisione Malattie Infettive, Azienda Ospedaliera di Parma, and Cattedra di Malattie Infettive, \\ Università di Parma, Parma, Italy; ${ }^{\ddagger}$ GlaxoWellcome, Research Triangle Park, North Carolina 27709; and ${ }^{\S}$ GlaxoWellcome, Verona, Italy
}

\begin{abstract}
High viral and/or antigen load may be an important cause of the $\mathrm{T}$ cell hyporesponsiveness to hepatitis $\mathrm{B}$ virus (HBV) antigens that is often observed in patients with chronic HBV infection. Reduction of viral and antigen load by lamivudine treatment represents an ideal model for investigating this hypothesis. HLA class II restricted $\mathrm{T}$ cell responses and serum levels of $\mathrm{HBV}-\mathrm{DNA}, \mathrm{HBsAg}$, and $\mathrm{HBeAg}$ were studied before and during lamivudine treatment in 12 patients with hepatitis $B$ e antigen positive chronic active hepatitis $B$ to assess possible correlations between viral and/or antigen load and vigor of the $\mathrm{T}$ cell response. Cell proliferation to $\mathrm{HBV}$ nucleocapsid antigens and peptides and frequency of circulating $\mathrm{HBV}$ nucleocapsid-specific $\mathrm{T}$ cells were assessed to characterize CD4-mediated responses. A highly significant enhancement of the CD4-mediated response to HBV nucleocapsid antigens was already detectable in most patients 7-14 d after the start of lamivudine treatment. This effect was dramatic and persistent in 10 patients but undetectable in 2 . It occurred concomitant with a rapid and marked reduction of viremia. Interestingly, lamivudine also enhanced the responses to mitogens and recall antigens, showing that its effect was not limited to $\mathrm{HBV}$ specific $\mathrm{T}$ cells. In conclusion, an efficient antiviral $\mathrm{T}$ cell response can be restored by lamivudine treatment in patients with chronic hepatitis $B$ concurrently with reduction of viremia, indicating the importance of viral load in the pathogenesis of $\mathrm{T}$ cell hyporesponsiveness in these patients. Since lamivudine treatment can overcome $T$ cell hyporeactivity, combining lamivudine with treatments directed to stimulate the $\mathrm{T}$ cell response may represent an effective strategy to induce eradication of chronic HBV infection. ( $J$. Clin. Invest. 1998. 102:968-975.) Key words: lamivudine • $\mathrm{T}$ cell response $\cdot$ antigen load $\bullet$ chronic hepatitis $\mathrm{B} \cdot$ viral persistence
\end{abstract}

\section{Introduction}

The T cell response plays a crucial role in protection against viral infections, and development of an efficient antiviral $\mathrm{T}$ cell

Address correspondence to Carlo Ferrari, M.D., Laboratorio di Immunopatologia Virale, Divisione Malattie Infettive, Azienda Ospedaliera di Parma, Via Gramsci 14, 43100 Parma, Italy. Phone: 39521-991-806; FAX: 39-521-998-706; E-mail: cafer@mbox.vol.it

Received for publication 15 April 1998 and accepted in revised form 25 June 1998.

J. Clin. Invest.

(C) The American Society for Clinical Investigation, Inc. 0021-9738/98/09/0968/08 \$2.00

Volume 102, Number 5, September 1998, 968-975

http://www.jci.org response is needed to avoid viral persistence and chronic evolution of virus-induced diseases $(1,2)$. Viral persistence is frequently associated with a state of $\mathrm{T}$ cell hyporesponsiveness, and recovery of the $\mathrm{T}$ cell reactivity is likely essential for resolution of chronic viral infections.

More than 300 million people worldwide are chronically infected with the hepatitis B virus (HBV). ${ }^{1}$ A defective antiviral $\mathrm{T}$ cell response has been documented in these patients (3-7) and may represent a critical pathogenetic determinant of viral persistence. Different mechanisms for this T cell hyporesponsiveness have been proposed (7), including a possible role of the high viral and antigen load typical of these patients, but the relevance of these factors has not been demonstrated.

Therapeutic strategies to enhance these defective responses have been proposed as possible alternatives to interferon (IFN; reference 8), the most effective drug available at present for the treatment of chronic hepatitis B (CH-B). However, all these treatments may be ineffective if $\mathrm{T}$ cells are nonresponsive to exogenous stimuli. Therefore, understanding the mechanisms responsible for $\mathrm{T}$ cell hyporeactivity in $\mathrm{CH}-\mathrm{B}$ may help identify rational therapeutic strategies to restore $\mathrm{T}$ cell responsiveness, thus allowing successful stimulation of antiviral $\mathrm{T}$ cell responses in vivo for obtaining long-lasting viral suppression and disease remission.

Recently, novel antiviral agents have been evaluated for their therapeutic potential for treatment of $\mathrm{CH}-\mathrm{B}$. Lamivudine, one of the most promising of such agents is a deoxycytosine analog which potently inhibits HBV DNA synthesis and rapidly suppresses serum $\mathrm{HBV}$ DNA levels in $\mathrm{CH}-\mathrm{B}$ patients $(9,10)$.

The potency of lamivudine for inhibiting HBV replication provides a possible avenue for clarifying whether viral and/or antigen load may contribute to $\mathrm{T}$ cell hyporesponsiveness of $\mathrm{CH}-\mathrm{B}$ patients. For this purpose, the $\mathrm{T}$ cell response was studied in a group of 12 patients with $\mathrm{CH}-\mathrm{B}$, both before and during treatment with lamivudine. Since lamivudine has no stimulatory activity on $\mathrm{T}$ cells $(11,12)$, it was anticipated that observed immunological effects in $\mathrm{CH}-\mathrm{B}$ patients would be due to lamivudine-induced viral suppression rather than to direct effects of lamivudine on $\mathrm{T}$ cells.

\section{Methods}

Patients. 12 patients (11 males and 1 female; mean age 32 years) with hepatitis B surface antigen ( $\mathrm{HBsAg}$ ) positive chronic hepatitis were enrolled. All patients had elevated serum alanine aminotransferase

1. Abbreviations used in this paper: ALT, alanine aminotransferase; anti-HBc, anti-core hepatitis B; APC, antigen-presenting cell; $\mathrm{CH}-\mathrm{B}$, chronic hepatitis $\mathrm{B}$; $\mathrm{HBcAg}$, recombinant hepatitis $\mathrm{B}$ core antigen; $\mathrm{HBeAg}$, hepatitis B e antigen; HBsAg, hepatitis B surface antigen; $\mathrm{HBV}$, hepatitis B virus; $\mathrm{HCV}$, hepatitis $\mathrm{C}$ virus; $\mathrm{HIV}$, human immunodeficiency virus; PBMC, peripheral blood mononuclear cell; PHA, phytohemagglutinin; SI, stimulation index. 
(ALT) values for at least $1 \mathrm{yr}$, and were hepatitis $\mathrm{B}$ e antigen (HBeAg) and HBV-DNA positive (HBV-DNA assay; Digene, Beltsville, MD), and antibody negative to delta, hepatitis $\mathrm{C}(\mathrm{HCV})$, and human immunodeficiency (HIV) viruses. Other possible causes of chronic liver damage, such as alcohol, drugs, congestive heart failure, and autoimmune diseases were excluded. Three patients had previously been treated with INF- $\alpha$ (more than $1 \mathrm{yr}$ before the start of the study) without clinical response.

Study design. The study protocol comprised 6 mo of patient monitoring before the start of treatment, followed by $12 \mathrm{mo}$ of lamivudine therapy (100 $\mathrm{mg}$ once a day) and 6 mo of follow-up after the end of therapy.

Clinical, virological, and immunological parameters were assessed in the study patients at baseline, at monthly intervals before the start of lamivudine therapy, and at 7, 14, and $30 \mathrm{~d}$, and every month thereafter during lamivudine therapy. The study was approved by the local Ethical Committee of the University Hospital of Parma. This interim report concerns the data obtained before therapy and the first 5 mo during therapy because lamivudine has a very fast antiviral activity which is already maximal after a few weeks of treatment.

At each assessment, patients were evaluated for HBV DNA, $\mathrm{HBe} \mathrm{Ag}$, anti-HBe, $\mathrm{HBsAg}$, and anti-HBs. An adverse event inquiry was completed, and blood samples were drawn for immunoassays, blood chemistry, and hematology.

Virological assessments. HBsAg, anti-HBs, total and immunoglobulin $\mathrm{M}$ anticore (anti-HBc), HBeAg, anti-HBe, antidelta, anti$\mathrm{HCV}$, and anti-HIV1 and anti-HIV2 were determined by commercial enzyme immunoassay kits (Abbott Laboratories, North Chicago, IL; Ortho Diagnostic Systems, Raritan, NJ; Sanofi Diagnostics Pasteur, Marnes-la-Coquette, France).

Quantitation of serum HBsAg and HBeAg was performed by comparing the optical densities of different serum sample dilutions with reference curves obtained from serial dilutions of recombinant HBsAg (Sorin Biomedica, Saluggia, Italy) and HBeAg (Biogen, Geneva, Switzerland) of known concentration. To avoid interassay variations in individual patients, sera derived from all different time points were tested simultaneously, and the same reference curve was used for antigen quantitation of all samples from each patient.

Antigens, mitogens, and synthetic peptides. Recombinant hepatitis B core antigen ( $\mathrm{HBcAg}$ ) was obtained as described previously (13) and determined to be $>95 \%$ pure. A HBcAg mutant lacking the carboxy-terminal 39 amino acid residues was purchased from Biogen (14). Its purity was $99.8 \%$, and it is herein designated as HBeAg. Tetanus toxoid was purchased from Connaught (Willowdale, Ontario, Canada). Phytohemagglutinin (PHA) (1:200, PHA-M; GIBCO BRL, Grand Island, NY) and mouse anti-human CD3 monoclonal antibody were used for total $\mathrm{T}$ cell stimulation. 26 peptides, 10-20 amino acids long, corresponding to the complete sequence of the core and precore region encoded polypeptides (subtype ayw), were purchased from Multiple Peptide System (La Jolla, CA) and Chiron Mimotopes (Clayton, Victoria, Australia).

Isolation of peripheral blood mononuclear cells (PBMCs) and T cell subsets. PBMCs were isolated from fresh heparinized blood by Ficoll-Hypaque density gradient centrifugation. T cells and non-T cells were separated by rosetting PBMCs with 2-aminoethylisothiuronium bromide (Sigma Chemical Co., St. Louis, MO) treated sheep erythrocytes (15), followed by Ficoll-Hypaque gradient centrifugation. The $\mathrm{T}$ cell-enriched population contained $>95 \% \mathrm{CD} 3+$ cells.

$\mathrm{CD} 4+$ and $\mathrm{CD} 8+\mathrm{T}$ cells were purified by immunomagnetic separation using Dynabeads (Dynal A.S., Oslo, Norway). The purity of T cell preparations was tested with fluorescein isothiocyanate or phycoerythrin-conjugated mAbs (CD4/CD8, CD3/19; Becton Dickinson Monoclonal Center, Inc., Mountain View, CA) on a FACSort flow cytometer. Cell populations were resuspended at $10^{6}$ cells $/ \mathrm{ml}$ in RPMI 1640 supplemented with $25 \mathrm{mM}$ Hepes, $2 \mathrm{mM}$ L-glutamine, 50 $\mu \mathrm{g} / \mathrm{ml}$ gentamycin, and $8 \%$ human serum (complete medium).

Proliferation assays. Unfractionated PBMCs $\left(2 \times 10^{5} /\right.$ well $)$ were incubated for $7 \mathrm{~d}$ at $37^{\circ} \mathrm{C}$ in the presence of HBV nucleocapsid anti- gens $(0.5 \mu \mathrm{g} / \mathrm{ml})$, synthetic peptides $(2.5 \mu \mathrm{g} / \mathrm{ml})$, or tetanus toxoid $(0.5$ $\mu \mathrm{g} / \mathrm{ml})$. In selected experiments, $10^{5} \mathrm{~T}$ cell subsets were cultured with autologous irradiated PBMCs $\left(10^{5}\right)$ or non-T cells $\left(2 \times 10^{4}\right)$ as antigen-presenting cells (APCs) in the presence or absence of antigens. All proliferation assays were performed in triplicate in 96-well plates and $\left[{ }^{3} \mathrm{H}\right]$ thymidine $\left({ }^{3} \mathrm{H}-\mathrm{TdR} ; 0.5 \mu \mathrm{Ci} /\right.$ well; specific activity, $2.0 \mathrm{Ci} /$ $\mathrm{mmol} /$ liter; Amersham International, Amersham, U.K.) was added $6 \mathrm{~h}$ before harvesting. Results are expressed as stimulation index (SI), which represents the ratio between the mean cpm obtained in the presence and absence of antigen or mitogen. For antigenic stimulations, SI values above 4 were regarded as positive ( $\geq 2$ SD above the mean SI value obtained with each individual HBV protein or peptide in normal controls).

Limiting dilution analysis. $\mathrm{HBe} \mathrm{Ag}$-specific $\mathrm{T}$ cell frequency was determined by limiting dilution analysis. Varying numbers of purified T cells $\left(1 \times 10^{5}, 6 \times 10^{4}, 3 \times 10^{4}, 1 \times 10^{4}, 3 \times 10^{3}, 1 \times 10^{3}, 3 \times 10^{2}\right.$, and $1 \times 10^{2}$ ) were cocultured in individual wells with a constant number of irradiated autologous non-T cells $\left(2 \times 10^{4}\right)$ in the presence or absence of $0.5 \mu \mathrm{g} / \mathrm{ml} \mathrm{HBeAg}$. 32 replicate wells were seeded for each concentration of responder T cells. ${ }^{3} \mathrm{H}-\mathrm{TdR}$ incorporation was measured after $7 \mathrm{~d}$. Individual cultures stimulated with antigen, showing ${ }^{3} \mathrm{H}-\mathrm{TdR}$ incorporation higher than the mean $+3 \mathrm{SD}$ of that shown by cultures incubated in the absence of antigen, were scored as positive. The fraction of nonresponder cultures was calculated for each concentration of seeded $\mathrm{T}$ cells. $\mathrm{T}$ cell frequency was calculated by Poisson analysis using the ELIDA computer program (16).

Determination of the cellular phenotype. PBMCs were analyzed by immunofluorescence on a fluorescence-activated cell sorter after staining with fluorescein isothiocyanate, phycoerythrin, or peridinin chlorophyll protein conjugated mouse monoclonal antibodies: anti-CD4, antiCD8, anti-DR, anti-CD45RA, anti-CD69, and anti-TCR purchased from Becton Dickinson and anti-CD45RO purchased from Sigma.

Statistical analysis. Stimulation indexes derived from patients before and during lamivudine treatment were compared by the Student's $t$ test for paired data and by the Mann-Whitney U test. Frequencies of significant proliferative $\mathrm{T}$ cell responses and of circulating antigen-specific $\mathrm{T}$ cells were compared by $\chi^{2}$ analysis.

\section{Results}

The vigor of the $T$ cell response to $H B c A g$ and $H B e A g$ is enhanced by lamivudine treatment. Taking advantage of the fact that lamivudine is a potent antiviral drug with no direct effect on the immune system $(11,12)$, we asked whether reduction of viral or antigen load determined by lamivudine treatment can cause a recovery of the $\mathrm{T}$ cell response in patients with chronic HBV infection who are generally hyporesponsive to HBV proteins.

$\mathrm{T}$ cell responses to $\mathrm{HBeAg}$ were undetectable in five consecutive determinations during the pretreatment period in 10 of the 12 patients (Fig. 1). T cell responses to $\mathrm{HBcAg}$ were more frequently measurable than responses to $\mathrm{HBe} \mathrm{Ag}$ during this period. In contrast, one patient (patient 11) displayed unusually strong basal levels of $\mathrm{T}$ cell proliferative response to both $\mathrm{HBeAg}$ and $\mathrm{HBcAg}$ before therapy. Responsiveness to $\mathrm{HBV}$ nucleocapsid antigens before treatment was unrelated to previous IFN therapy because only one of the responsive patients had previously been treated with IFN (patient 11).

Lamivudine treatment was associated with an increase in the strength of the $\mathrm{T}$ cell responses to HBV antigens in 10 of the 12 patients, and the difference between pretreatment and during-treatment responses was statistically significant in 8 and 9 patients for the $\mathrm{T}$ cell response to $\mathrm{HBeAg}$ and $\mathrm{HBcAg}$, respectively (by the Mann-Whitney U test; Fig. 1). This result was highly significant when the patient population was analyzed as a whole. 


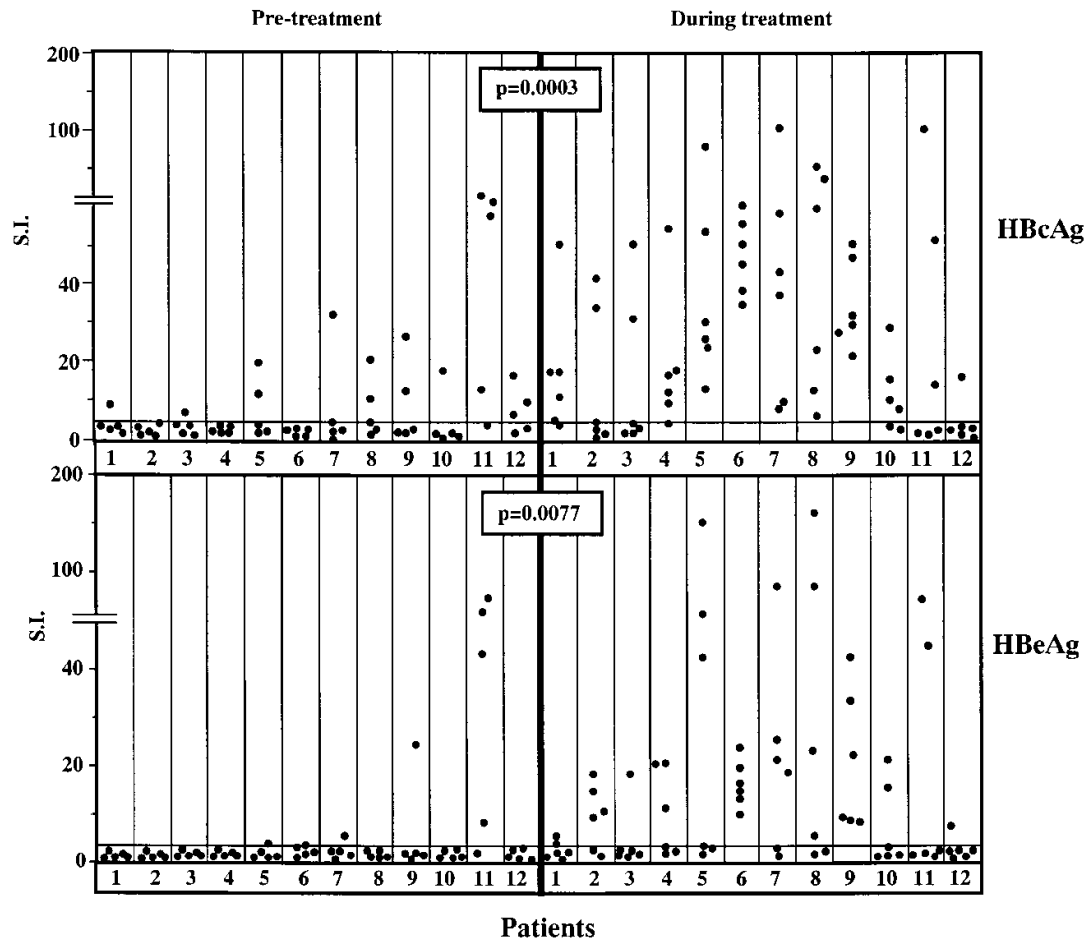

Figure 1. Proliferative T cell response to $\mathrm{HBcAg}$ and $\mathrm{HBeAg}$ expressed by 12 patients with $\mathrm{HBeAg}+\mathrm{CH}-\mathrm{B}$ before and during $5 \mathrm{mo}$ of lamivudine treatment. The dots contained in each vertical lane represent the proliferative responses of individual patients at different time points. Values for the whole patient population before and during treatment were compared by the Student's $t$ test for paired data. Values for individual patients before and during treatment were compared with the Mann-Whitney U test; statistically significant differences were observed in all patients except patients 2,3,11, and 12 for the $\mathrm{T}$ cell responses to $\mathrm{HBcAg}$ and patients 1,11 , and 12 for the T cell responses to $\mathrm{HBe} \mathrm{Ag}$.

Consistent with this enhanced $\mathrm{T}$ cell responsiveness, the frequency of peripheral blood $\mathrm{HBeAg}$-specific $\mathrm{T}$ cells increased from generally undetectable levels ( $<1$ antigen-specific $\mathrm{T}$ cell per 300,000 total $\mathrm{T}$ cells) before lamivudine therapy to $>1: 50,000$ total $\mathrm{T}$ cells in most experiments, with peak levels of $>1: 5,000 \mathrm{~T}$ cells (Fig. 2). These frequencies are comparable to those detectable in patients with acute infection who recover spontaneously from disease (data not shown).

Enhanced T cell responses were evident within 1 or $2 \mathrm{wk}$ after the start of lamivudine therapy in eight patients, and by wk 4 of treatment in two others. T cell responsiveness did not change in two patients after the initiation of therapy. Overall, the $\mathrm{T}$ cell response to $\mathrm{HBcAg}$ at all time points after the start of treatment differed significantly from that observed at the final time point (wk 24) preceding therapy (Fig. 3). For the T cell response to $\mathrm{HBeAg}$, this comparison was significant only at wks 28,36 , and 40.

$\mathrm{T}$ cell proliferative responses were mostly sustained by CD4+ T cells, as shown by experiments with purified CD4 or $\mathrm{CD} 8+\mathrm{T}$ cells as effectors cocultured with irradiated PBMCs as APC (data not shown). The distribution of $\mathrm{T}$ cell subsets and the expression of surface $\mathrm{T}$ cell activation markers did not differ before and during lamivudine therapy.

$T$ cell reactivity to overlapping peptides corresponding to the core and precore region-encoded polypeptides was also enhanced by lamivudine therapy. The frequency of significant

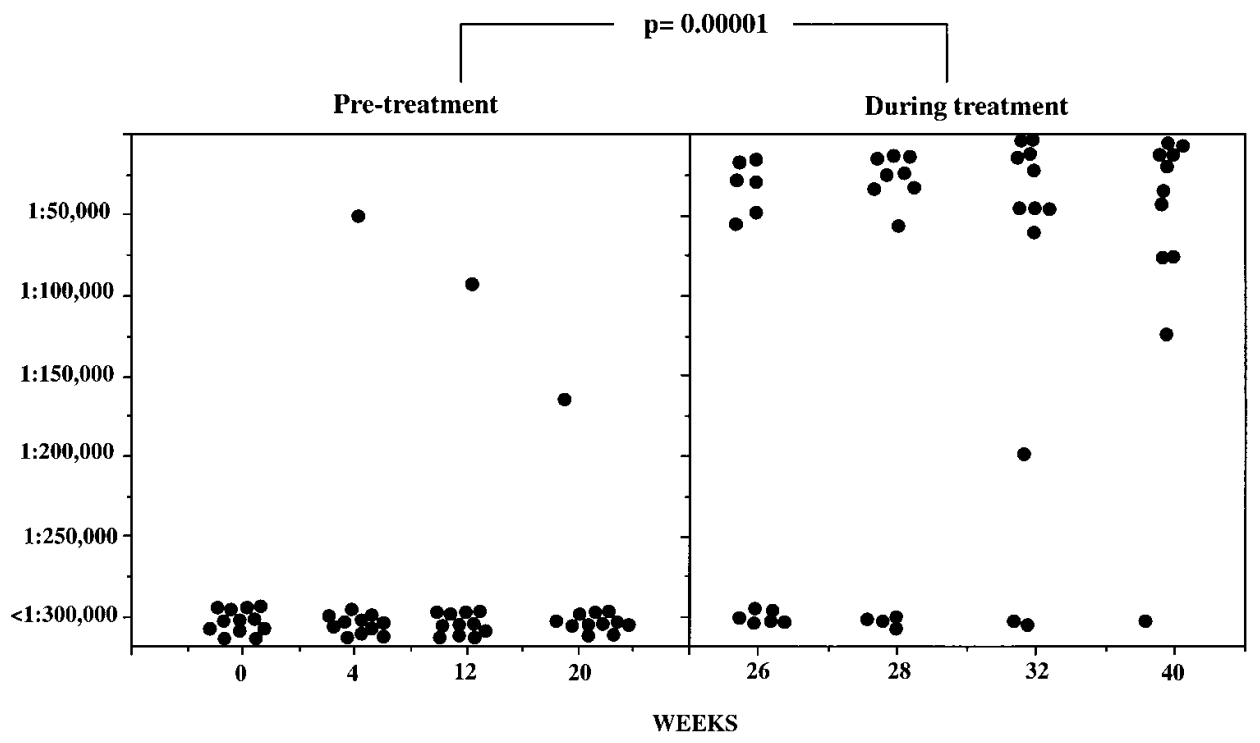

Figure 2. Frequency of circulating $\mathrm{HBeAg}$-specific T cells in $12 \mathrm{CH}-\mathrm{B}$ patients before and during lamivudine treatment. Frequencies were determined by limiting dilution analysis. Statistical comparison was made by the Chi-square test. Frequencies were determined only at those time points when a sufficient number of PBMCs were available for the assay. 


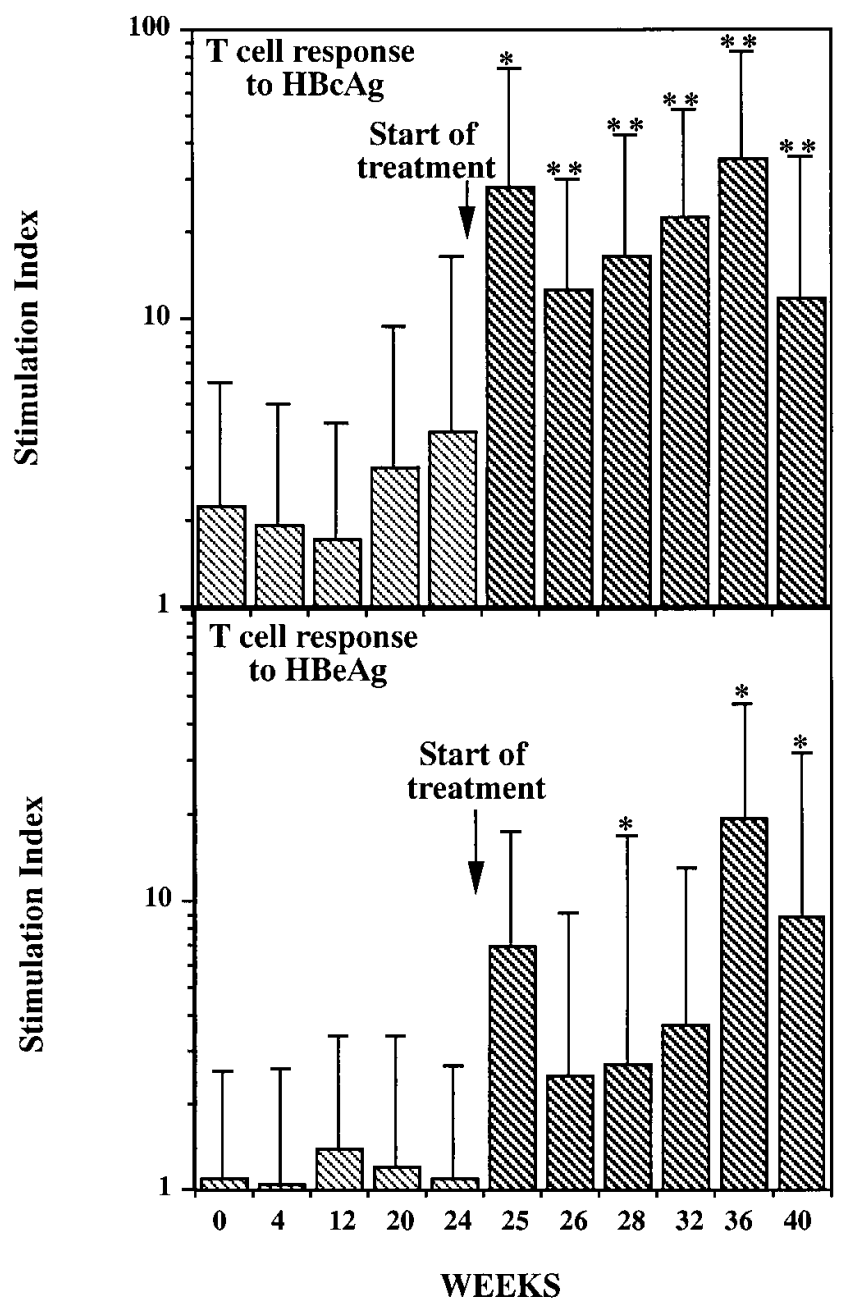

Figure 3. Proliferative T cell response to $\mathrm{HBcAg}$ and $\mathrm{HBeAg}$ displayed by $12 \mathrm{CH}-\mathrm{B}$ patients before and during 5 mo of lamivudine treatment. Each bar represents the median stimulation index for all patients at each time point. Data for each time point during therapy were compared with data for wk 24 (preceding start of therapy) by the Student's $t$ test for paired data. $* P=0.01-0.05 ; * * P<0.01$.

responses $(\mathrm{SI}>4)$ rose sharply after the start of lamivudine therapy for peptides 91-110, 100-119, 111-125, 117-131, precore 13-29, and precore 20-2 core (Fig. 4). Multiple peptides were recognized simultaneously by individual patients, indicating that the $\mathrm{T}$ cell responses were generally multispecific (Fig. 5). Moreover, responses to individual peptides tended to fluctuate. Consistent responses to a given peptide throughout the treatment period were noted in relatively few instances, and the combinations of peptides recognized by patients tended to vary at the different time points.

Recovery of $T$ cell responsiveness is temporally associated with the drop of serum HBV DNA concentrations. Serum HBV DNA dropped rapidly in all patients after the start of lamivudine treatment and became undetectable in nine of them. This decline of serum HBV DNA was associated temporally with a marked increase of circulating HBeAg-reactive T cells in 10 of 12 patients (Fig. 6).

Lamivudine treatment was also associated with a decline in viral antigenemia in most patients. The serum HBeAg concentration declined in 10 of 12 patients, and 3 patients became
HBeAg negative (Table I). Four patients seroconverted to anti-HBe (one remained positive for both $\mathrm{HBeAg}$ and anti$\mathrm{HBe}$ ). Serum HBsAg concentrations declined moderately in 6 of 12 patients.

The decline of viral antigens in the serum was frequently slower and more gradual than decreases of HBV DNA. Minimal levels of antigenemia were generally reached when maximal levels of $\mathrm{T}$ cell responsiveness had already been restored.

The recovery of the $T$ cell reactivity is not limited to $H B V$ specific responses. The $\mathrm{T}$ cell response to mitogens and recall antigens was studied sequentially before and during lamivudine therapy to determine whether lamivudine enhances only $\mathrm{HBV}$-specific responses or the overall $\mathrm{T}$ cell reactivity. Responses were compared with those observed in a group of normal, uninfected subjects studied at different time points (to control for normal fluctuations of these responses over time).

T cell responses to PHA, anti-CD3, and tetanus toxoid before treatment were significantly lower than those observed in the control group (Fig. 7). Interestingly, lamivudine treatment was associated with an enhancement of all responses to a level comparable to those observed in the control group.

\section{Discussion}

Patients with chronic HBV infection are generally hyporesponsive to HBV proteins, and the level of T cell reactivity at this stage of infection is significantly weaker than in acute selflimited hepatitis B. This different vigor of the $\mathrm{T}$ cell response has been proposed to represent an important determinant of the final outcome of infection (7).

Little is known about the mechanisms responsible for the $\mathrm{T}$ cell hyporeactivity of patients with chronic HBV infection. Among different possible explanations, it is widely suspected that the high viral and antigen loads typical of these patients represent an important cause of this hyporesponsiveness, but direct evidence for this has never been provided.

The present study investigated whether decreases of viral or antigen load induced by lamivudine are associated with improvement of $\mathrm{T}$ cell responsiveness and whether $\mathrm{T}$ cell reactivity is enhanced generally or restricted to the virus-specific component of the immune response. The HBV-specific $\mathrm{T}$ cell response was studied with $\mathrm{HBV}$ nucleocapsid antigens $(\mathrm{HBcAg}$ and $\mathrm{HBeAg}$ ) because they represent the most powerful immunogens for HLA class II restricted, CD4+ T cells in HBV infection $(3,4)$. All study patients were positive for serum HBeAg and HBV-DNA and exhibited persistent ALT elevations. As expected, lamivudine treatment led to a rapid drop of viremia in all patients and a slower, more variable decrease of serum $\mathrm{HBeAg}$ concentrations. Most patients experienced improvements in serum ALT values after initiation of lamivudine therapy. Effects on HBsAg concentration were minimal during this short-duration therapy.

In most patients, treatment was followed rapidly by a marked increase of $\mathrm{T}$ cell responses to $\mathrm{HBcAg}$ and $\mathrm{HBeAg}$. There was a clear temporal association between the decline of viremia and recovery of the $\mathrm{T}$ cell reactivity to $\mathrm{HBV}$ antigens (Fig. 6). Both enhanced proliferative responses to HBV proteins or synthetic peptides, and increased frequencies of circulating $\mathrm{HBeAg}$-reactive $\mathrm{T}$ cells were generally preceded by, or temporally associated with, the decline of serum HBV DNA (Fig. 6). In a few patients, the frequency of HBeAg-reactive T cells was already measurable before the start of therapy (pa- 
Percentage of patients responsive to individual peptides
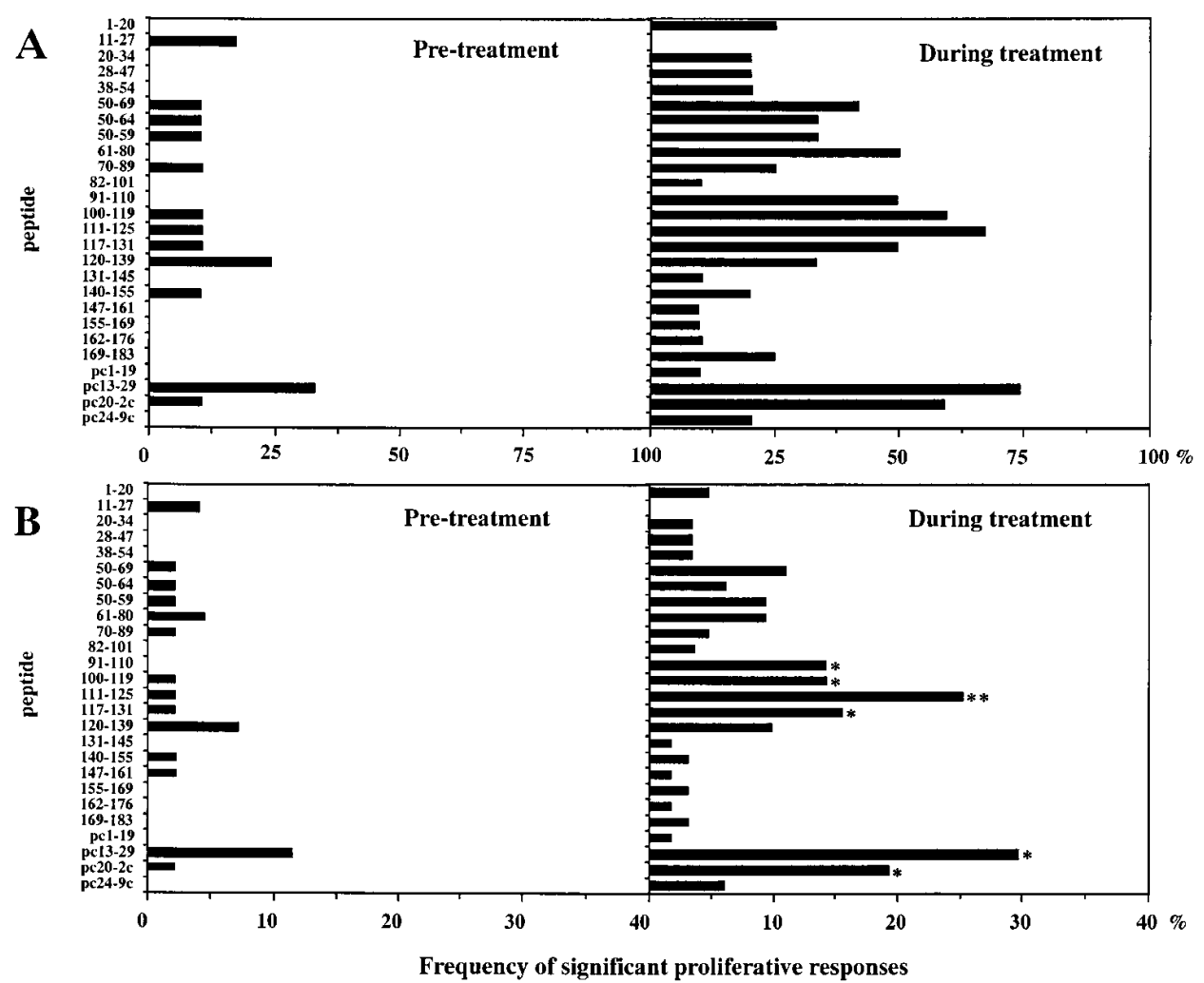

Figure 4. (A) Percentage of study patients responsive to $\mathrm{HBcAg}$ synthetic peptides before and during 5 mo of lamivudine treatment. (B) Frequency of significant proliferative T cell responses to $\mathrm{HBcAg}$ synthetic peptides expressed by 12

$\mathrm{CH}-\mathrm{B}$ patients before and during 5 mo of lamivudine treatment. Data before and during treatment were compared by the Chi-square test. $* P=0.01-0.05 ; * * P<0.01$.

Table I. Behavior of Serum ALT, HBsAg, and HBeAg Values under Lamivudine Treatment Compared with Pretreatment Levels (Wk 24)

\begin{tabular}{|c|c|c|c|c|c|c|c|c|c|c|c|c|}
\hline Weeks & 1 & 2 & 3 & 4 & 5 & 6 & 7 & 8 & 9 & 10 & 11 & 12 \\
\hline \multicolumn{13}{|l|}{ ALT } \\
\hline pre & 161 & 111 & 108 & 126 & 61 & 220 & 190 & 598 & 374 & 130 & 691 & 60 \\
\hline 25 & 142 & 42 & 32 & 108 & 48 & 135 & 125 & 241 & 36 & 94 & 592 & 28 \\
\hline 26 & 137 & ND & 33 & 65 & 42 & 115 & 140 & 350 & 44 & 72 & 494 & 26 \\
\hline 28 & 114 & 44 & 35 & 48 & 56 & 123 & 155 & 226 & 41 & 126 & 254 & 29 \\
\hline 32 & 53 & 44 & 30 & 58 & 47 & 111 & 140 & 52 & 51 & 177 & 79 & 23 \\
\hline 36 & 40 & 44 & 26 & 39 & 47 & 88 & 209 & 34 & 45 & 99 & 51 & 23 \\
\hline 40 & 36 & 54 & 41 & 42 & 59 & 112 & 82 & 29 & 34 & 71 & 45 & 21 \\
\hline \multicolumn{13}{|c|}{$\operatorname{HBs} A g(\mu \mathrm{g} / \mathrm{ml})$} \\
\hline pre & 4.8 & 1.2 & 13 & 0.4 & 110 & 150 & 8 & 14 & 4.5 & 28 & 24 & 4.1 \\
\hline 25 & 6.1 & 0.7 & 14 & 0.3 & 120 & 92 & 8 & 14 & 4.8 & 35 & 11 & 5.6 \\
\hline 26 & 5.3 & ND & 14 & 0.2 & 110 & 91 & 6 & 12 & 4.8 & 24 & 12 & 4.3 \\
\hline 28 & 5.0 & 1.3 & 15 & 0.5 & 105 & 91 & 5 & 13 & 5.0 & 20 & 10 & 5.0 \\
\hline 32 & 5.6 & 1.9 & 17 & 0.7 & 90 & 64 & 5 & 7 & 4.2 & 15 & 8 & 5.0 \\
\hline 36 & 5.6 & 1.2 & 14 & 0.7 & 85 & 38 & 3 & 7 & 3.0 & 10 & 7 & 4.6 \\
\hline 40 & 7.9 & 2.1 & 12 & 0.8 & 67 & 24 & 1 & 7 & 4.5 & 5 & 10 & 4.5 \\
\hline \multicolumn{13}{|c|}{$\mathrm{HBe} A g(\mathrm{ng} / \mathrm{ml})$} \\
\hline pre & 470 & 15 & 30 & 8 & 7000 & 4100 & 1330 & 96 & 570 & 1920 & 950 & 2440 \\
\hline 25 & 760 & 19 & 20 & 3.9 & 7000 & 3600 & 1650 & 164 & 700 & 2300 & 440 & 2700 \\
\hline 26 & 530 & ND & 19 & 0.1 & 5300 & 3750 & 1205 & 224 & 610 & 1900 & 180 & 1860 \\
\hline 28 & 360 & 15 & 10 & NEG & 5600 & 4200 & 1140 & 199 & 520 & 1620 & 60 & 2800 \\
\hline 32 & 200 & 10 & 6 & NEG & 4200 & 2750 & 730 & 31 & 225 & 1180 & 26 & 2040 \\
\hline 36 & 140 & 10 & 3 & NEG & 4600 & 1500 & 151 & 10 & 95 & 930 & 3 & 2600 \\
\hline 40 & 120 & 12 & 2 & NEG & 3500 & 1100 & NEG & 5 & 87 & 370 & NEG & ND \\
\hline
\end{tabular}

$\mathrm{ND}=$ not determined; $\mathrm{NEG}=$ negative 


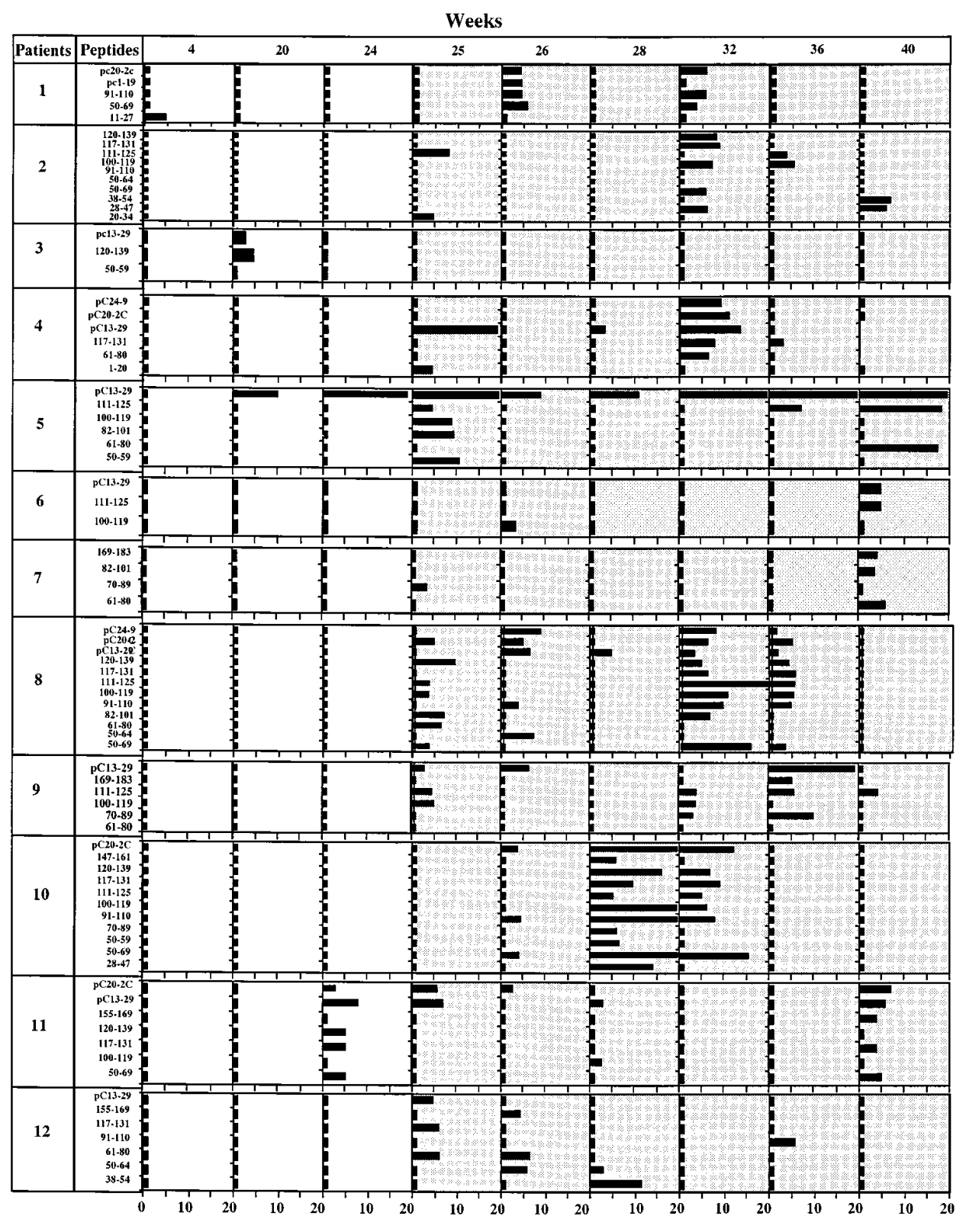

Stimulation Index
Figure 5. Longitudinal analysis of the $\mathrm{T}$ cell proliferative response to HBV core peptides by PBMCs of 12 patients with $\mathrm{CH}-\mathrm{B}$. The figure illustrates the response at different time points to only those peptides to which individual patients gave at least one significant response. Responses were tested only when a sufficient number of PBMCs were available; for this reason, some time points are missing. tients $1,4,7$, and 11 ), but $\mathrm{T}$ cell frequencies never exceeded 1 antigen-specific T cell per 50,000 total T cells (Fig. 6).

Overall, the strength of the $\mathrm{T}$ cell response to $\mathrm{HBeAg}$ and $\mathrm{HBcAg}$ was significantly greater during than before lamivudine treatment. Only two patients (patients 11 and 12) did not show significant enhancements of $\mathrm{T}$ cell responsiveness despite a rapid drop of HBV-DNA caused by lamivudine treatment. Patient 12, the only Oriental patient in the study, was believed to be infected perinatally. Genetic factors and/or the route of infection may have influenced her different immunological response. Patient 11 exhibited elevated ALT levels and T cell resposiveness to $\mathrm{HBV}$ proteins before lamivudine treatment. $\mathrm{He}$ had previously been treated with INF- $\alpha 10 \mathrm{yr}$ before entering the present study. These factors suggest a reactivation of liver disease which can be associated with increased $\mathrm{T}$ cell reactivity to HBV nucleocapsid antigen $(17,18)$ and often precedes spontaneous HBV clearance and resolution of the disease process.

Our data suggest that lamivudine can break the state of $\mathrm{T}$ cell nonresponsiveness in a large proportion of $\mathrm{HBeAg}$ positive patients. Although $\mathrm{HBeAg}$ clearance was observed in a few patients, the increased $T$ cell reactivity induced by lamivudine was not sufficient to cause extensive anti-HBV seroconversion. Thus, combining lamivudine therapy with other agents able to stimulate the antiviral $\mathrm{T}$ cell response directly and specifically may be a rational strategy for treating chronic HBV infection. The observation that enhanced $T$ cell responses occurred in 10 of 12 patients by wk 4 of lamivudine therapy may be relevant to the issue of when to initiate adjunctive immunomodulatory therapies. This may be particularly important when lamivudine is combined with a T cell growthinhibitory drug such as IFN- $\alpha$. Indeed, the antiproliferative 

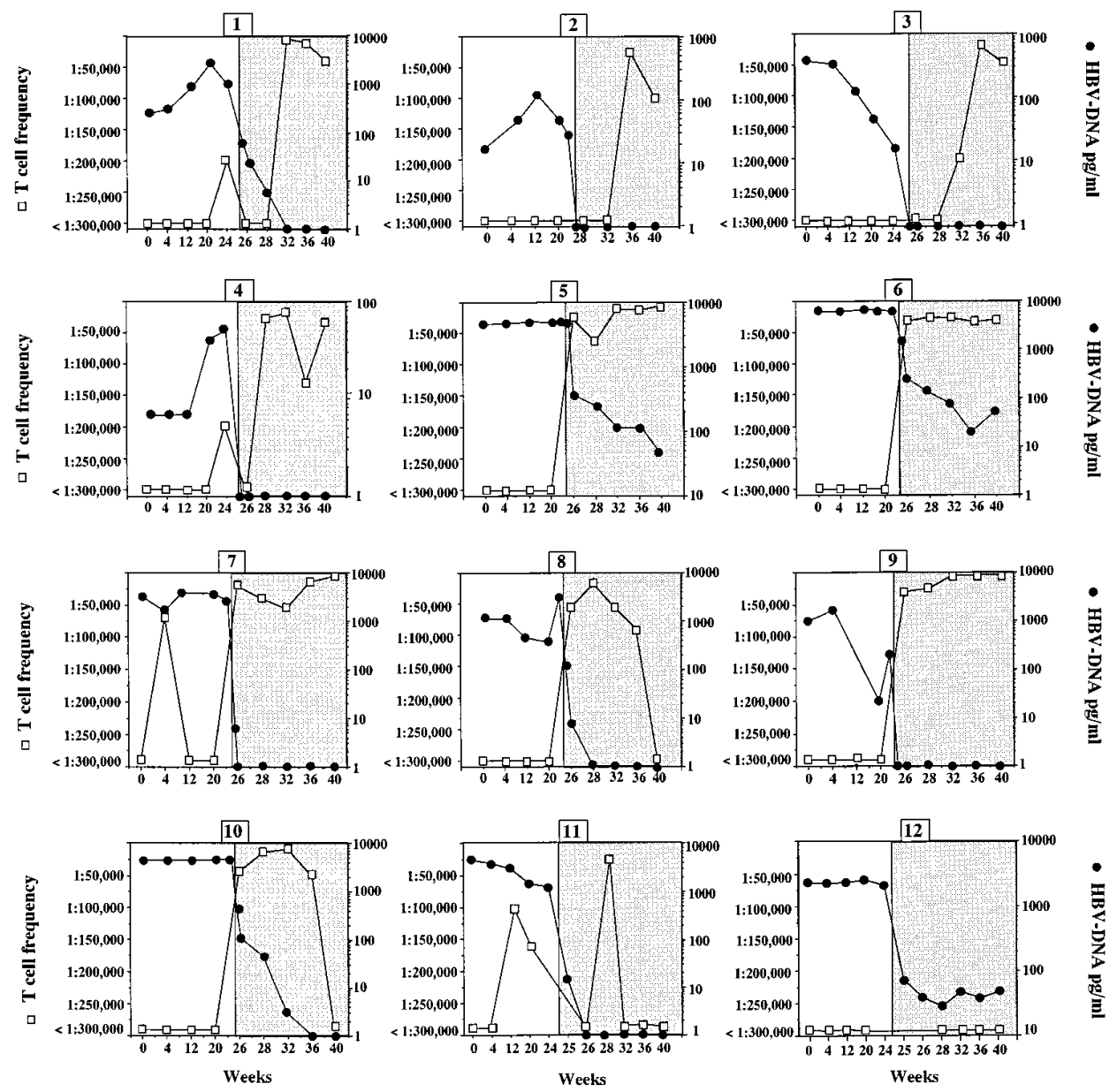

action of IFN- $\alpha$ on $\mathrm{T}$ cells requires the recruitment by the IFN- $\alpha$ receptor signaling complex of components needed for $\mathrm{T}$ cell receptor (TCR) engagement (19). If recovery of $\mathrm{T}$ cell reactivity by lamivudine is ultimately mediated by effector mechanisms able to restore signal transduction through the TCR, one could speculate that IFN can prevent lamivudine effect on T cells by perturbing TCR signaling when both drugs are administered simultaneously. If this is the case, lamivudine and IFN should be given sequentially rather than simultaneously. For this reason, Marinos et al. may not have found significant effects on helper $\mathrm{T}$ cell responses to $\mathrm{HBcAg}$ in their population of patients treated with a combination of lamivudine and IFN (20). Alternatively, their different results may be related to different patient selection, most of the patients being naive in our study instead of IFN nonresponders as in Marinos's report.

While enhancement of $\mathrm{T}$ cell responses was clearly associated temporally with decreases in viremia (serum HBV DNA) in 10 of the 12 patients studied, the relationship between reduction of the serum HBeAg concentration and recovery of $\mathrm{T}$ cell responses was less clear. A slight decrease of $\mathrm{HBeAg}$ concentration preceded increased $\mathrm{T}$ cell reactivity in approximately half of the patients, but in all patients the reduction of antigen load was gradual, and antigenemia continued to decline after $\mathrm{T}$ cell reactivity had reached its maximum. Thus, it is unlikely that recovery of $\mathrm{T}$ cell reactivity is related to the decline of serum $\mathrm{HBeAg}$, but this possibility cannot be excluded since it is totally unknown to what extent antigenemia must decline in vivo to allow $\mathrm{T}$ cells to restore their reactivity.

One possible mechanism for the $\mathrm{T}$ cell hyporesponsiveness observed in patients with chronic hepatitis B is deletion of immunodominant $\mathrm{T}$ cell populations by exhaustion (21-23), possibly caused by high serum antigen concentrations. However, the $\mathrm{T}$ cell response to synthetic peptides seems to rule out this possibility. Comparison of the present results with those obtained previously in patients with selflimited acute HBV infection (24) shows that the immunodominant amino acid sequences for induction of $\mathrm{T}$ cell responses are the same at both stages of infection, although some differences in the frequency of responses to individual peptides are obviously observed as a likely consequence of the heterogeneous genetic background of the two groups of patients.

The results obtained with $\mathrm{T}$ cell mitogens and tetanus toxoid show that the overall $\mathrm{T}$ cell pool was influenced by lamivudine treatment, not only the reactivity of virus-specific T cells. This finding, coupled with the observation that $\mathrm{T}$ cell responses generally increased before disease improved (ALT reduction), suggests that enhanced peripheral blood $\mathrm{T}$ cell responsiveness associated with lamivudine treatment is not due to the migration of $\mathrm{HBV}$-specific $\mathrm{T}$ cells from the liver to the blood, subsequent to decreased liver inflammation.

Overall, this study suggests that the basic $\mathrm{T}$ cell defect in patients with chronic HBV infection is sustained by antigen nonspecific mechanisms, which are able to act on all $\mathrm{T}$ cells 


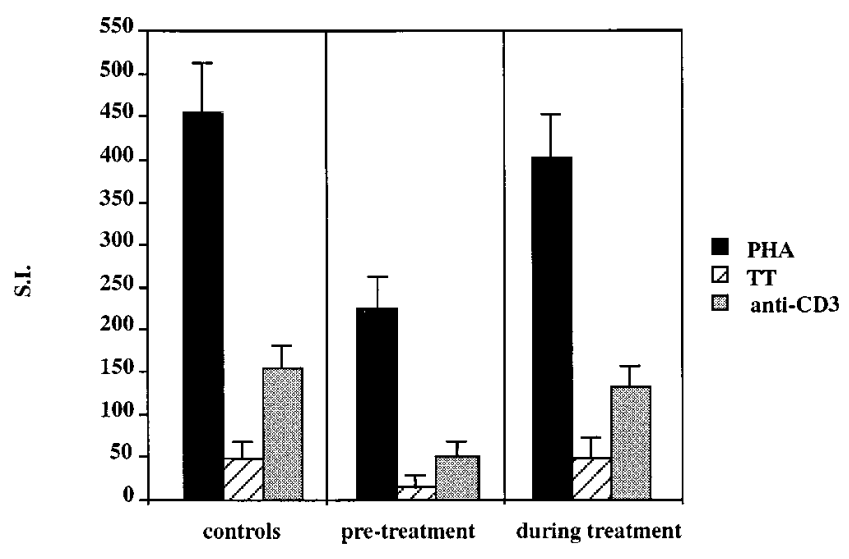

Figure 7. Mean values of proliferative response to PHA, anti-CD3, and tetanus toxoid (TT) displayed by 8 normal controls and 12 patients with $\mathrm{CH}-\mathrm{B}$ before and during 5 mo of lamivudine treatment. Each bar represents the mean stimulation index $( \pm \mathrm{SE})$ of sequential proliferation assays carried out in each individual (controls and chronic patients). Statistical comparisons were made by the Student's $t$ test for paired data. PHA: controls vs pre-treatment, $P=0.0007$; pre-treatment vs post-treatment, $P=0.0001$. TT: controls vs pretreatment, $P=0.0316$; pre-treatment vs post-treatment, $P=0.0006$. Anti-CD3: controls vs pre-treatment, $P=0.0001$; pre-treatment vs post-treatment, $P=0.0001$.

without regard to their antigen specificity. With respect to this interpretation, it will be useful to study the prevalent cytokine pattern of $\mathrm{HBeAg}+$ patients with chronic hepatitis and possible modifications that are induced by treatment.

Moreover, this study suggests that HBV, or specific HBVencoded amino acid sequences (including $\mathrm{HBeAg}$ and perhaps other proteins), can interfere with general functions or effector molecules of the immune system. This may lead to T cell hyporesponsiveness, as described for other viruses that can interfere with the biological activity of cytokines or their receptors (25-28) or inhibit signal transduction via protein kinase C, thereby affecting the overall $\mathrm{T}$ cell reactivity.

These results, which suggest that viral load contributes to persistent $\mathrm{T}$ cell hyporeactivity in chronic HBV infection, also have practical implications for treatment of chronic hepatitis B. Inhibition of viral replication with agents such as lamivudine may enhance the likelihood that therapeutic stimulation of the $\mathrm{T}$ cell response will induce $\mathrm{HBV}$ antigen seroconversion, ultimately leading to recovery from disease. Further clinical studies are needed to explore this possibility.

\section{Acknowledgments}

This work was supported by a grant from GlaxoWellcome and in part by the National Institutes of Health (grant AI-26626), USA, and by the Ministry of Universities and Scientific and Technological Research (project on Liver Cirrhosis and Viral Hepatitis), Italy.

\section{References}

1. Oldstone, M.B.A. 1991. Molecular anatomy of viral persistence. J. Virol. 65:6381-6383.

2. Doherty, P.C., and R. Ahmed. 1997. Immune response to viral infection. In Viral Pathogenesis. N. Nathanson, editor. Lippincott-Raven Publishers, Philadelphia. 143-161.

3. Ferrari, C., A. Penna, A. Bertoletti, A. Valli, A.D. Antoni, T. Giuberti,
A. Cavalli, M.-A. Petit, and F. Fiaccadori. 1990. Cellular immune response to hepatitis B virus-encoded antigens in acute and chronic hepatitis B virus infection. J. Immunol. 145:3442-3449.

4. Jung, M., U. Spengler, W. Schraut, R. Hoffman, R. Zachoval, J. Eisemburg, D. Eichenlaub, G. Riethmuller, G. Paumgartner, H.W.L. Ziegler-Heitbrock, et al. 1991. Hepatitis B virus antigen-specific T-cell activation in patients with acute and chronic hepatitis B. J. Hepatol. 13:310-317.

5. Penna, A., F.V. Chisari, A. Bertoletti, G. Missale, P. Fowler, T. Giuberti, F. Fiaccadori, and C. Ferrari. 1991. Cytotoxic T lymphocytes recognize an HLA-A2-restricted epitope within the hepatitis B virus nucleocapsid antigen. $J$. Exp. Med. 174:1565-1570.

6. Nayersina, R., P. Folwer, S. Guilhot, G. Missale, A. Cerny, H.-J. Schlicht, A. Vitiello, R. Chesnut, J.L. Person, A.G. Redeker, et al. 1993. HLA A2 restricted cytotoxic T lymphocyte responses to multiple hepatitis B surface antigen epitopes during hepatitis B virus infection. J. Immunol. 150:4659-4671.

7. Chisari, F.V., and C. Ferrari. 1995. Hepatitis B virus immunopathogenesis. Annu. Rev. Immunol. 13:29-60.

8. Vitiello, A., G. Ishioka, H.M. Grey, R. Rose, P. Farness, R. LaFond, L. Yuan, and R. Chesnut. 1995. Development of a lipopeptide-based therapeutic vaccine to treat chronic HBV infection. I. Induction of a primary cytotoxic $\mathrm{T}$ lymphocyte response in humans. J. Clin. Invest. 95:341-349.

9. Doong, S.L., C.H. Tsai, R.F. Schinazi, D.C. Liotta, and Y.C. Cheng. 1991. Inhibition of the replication of hepatitis B virus in vitro by $2^{\prime}, 3^{\prime}$-dideoxy-3'-thiacytidine and related analogues. Proc. Natl. Acad. Sci. USA. 88:8495-8499.

10. Dienstag, J.L., R.P. Perrillo, E.R. Schiff, M. Bartholomew, C. Vicary, and M. Rubin. 1995. A preliminary trial of lamivudine for chronic hepatitis B infection. N. Engl. J. Med. 333:1657-1661.

11. Lisignoli, G., A. Facchini, L. Cattini, M.C.G. Monaco, A. Degrassi, and E. Mariani. 1992. In vitro toxicity of $2^{\prime}, 3^{\prime}$-dideoxy-3'-thiacytidine (BCH189/3TC), a new synthetic anti-HIV-1 nucleoside. Antiviral Chem. and Chemother. 3:299-303.

12. Lisignoli, G., M.C.G. Monaco, A. Degrassi, S. Toneguzzi, E. Ricchi, P. Costigliola, and A. Facchini. 1993. In vitro immunotoxicity of $2^{\prime}$-deoxy-3'-thiacytidine, a new anti-HIV agent. Clin. Exp. Immunol. 92:455-459.

13. Pasek, M., T. Goto, W. Gilbert, B. Zink, H. Schaller, P. Mackay, G. Leadbetter, and K. Murray. 1979. Hepatitis B virus genes and their expression in E. coli. Nature. 282:575.

14. Milich, D.R., A. McLachlan, S. Stahl, P. Wingfield, G.B. Thornton, J.L. Hughes, and J.E. Jones. 1988. Comparative immunogenicity of hepatitis B virus core and e antigens. J. Immunol. 141:3617-3624.

15. Saxon, A., J. Feldhaus, and R.A. Robins. 1976. Single step separation of human T and B cells using AET-treated sheep red cells. J. Immunol. Methods. 12:285-290.

16. Taswell, C. 1986. Limiting dilution assays for the separation, characterization, and quantitation of biologically active particles and their clonal progeny. In Cell Separation: Selected Methods and Applications. A. Pretlow and P. Pretlow, editors. Academic Press, New York. 120-141.

17. Tsai, S.L., P.J. Chen, M.Y. Lai, P.M. Yang, J.L. Sung, J.H. Huang, L.H. Hwang, T.H. Chang, and D.S. Chen. 1992. Acute exacerbations of chronic type B hepatitis are accompanied by increased $\mathrm{T}$ cell responses to hepatitis $\mathrm{B}$ core and $\mathrm{e}$ antigens. Implications for hepatitis B e antigen conversion. J. Clin. Invest. 89:87-96.

18. Maruyama, T., S. Iino, K. Koike, K. Yasuda, and D.R. Milich. 1993. Serology of acute exacerbation in chronic hepatitis B virus infection. Gastroenterology. 105:1141-1151.

19. Petricoin, E.F., S. Ito, B.L. Williams, S. Audet, L.F. Stancato, A. Gamero, K. Clouse, P. Grimley, A. Weiss, J. Beeler, et al. 1997. Antiproliferative action of interferon-a requires components of T-cell-receptor signalling. Nature. 390:629-632.

20. Marinos, G., N.V. Naoumov, and R. Williams. 1996. Impact of complete inhibition of viral replication on the cellular immune response in chronic hepatitis B virus infection. Hepatology. 24:991-995.

21. Webb, S., C. Morris, and J. Sprent. 1990. Extrathymic tolerance of mature T cells: clonal elimination as a consequence of immunity. Cell. 63:1249-1256.

22. Moskophidis, D., F. Lechner, H. Pircher, and R.M. Zinkernagel. 1993. Virus persistence in acutely infected immunocompetent mice by exhaustion of antiviral cytotoxic effector T cells. Nature. 362:758-762.

23. Critchfield, J.M., M.K. Rache, J.C. Zùniga-Pflucker, B. Cannella, C.S. Raine, J. Goverman, and M.J. Lenardo. 1994. T cell deletion in high antigen dose therapy of autoimmune encephalomyelitis. Science. 263:1139-1143.

24. Ferrari, C., A. Bertoletti, A. Penna, A. Cavalli, A. Valli, G. Missale, M. Pilli, P. Fowler, T. Giuberti, F.V. Chisari, et al. 1991. Identification of immunodominant $\mathrm{T}$ cell epitopes of the hepatitis B virus nucleocapsid antigen. J. Clin. Invest. 88:214-222.

25. Alcamì, A., and G.L. Smith. 1995. Cytokine receptors encoded by poxviruses: a lesson in cytokine biology. Immunol. Today. 16:474-478.

26. Hsu, D.H., R. de Waal Malefyt, F. Fiorentino, M.N. Dang, P. Vieira, J. deVries, and H. Spits. 1996. Expression of interleukin-10 activity by EpsteinBarr virus protein BCRF1. Science. 250:830-832.

27. Moore, K.W., P. Vieira, D.F. Fiorentino, M.L. Trounstine, T.A. Khan, and T.R. Mosmann. 1990. Homology of cytokine synthesis inhibitory factor (IL10) to the Epstein-Barr virus gene BCRF1. Science. 248:1230-1234.

28. Gooding, L.R. 1992. Virus proteins that counteract host immune defense. Cell. 71:5-7. 